\title{
Curricular Reform in Slovakia Regarding the Attitudes of Basic School Teachers ${ }^{1}$
}

\section{Štefan Porubský ${ }^{a}$, Marian Trnka $^{\mathrm{b}}$, Vladimír Poliach ${ }^{\mathrm{c}}$, Radka Cachovanová ${ }^{\mathrm{d}}$}

\begin{abstract}
${ }^{a}$ Matej Bel University in Banská Bystrica, Faculty of Education, Educational Research Center
${ }^{\mathrm{b}}$ Matej Bel University in Banská Bystrica, Faculty of Education, Department of Elementary and Preschool Education

${ }^{\mathrm{c}}$ Matej Bel University in Banská Bystrica, Faculty of Education, Department of Psychology

${ }^{\mathrm{d}}$ Matej Bel University in Banská Bystrica, Faculty of Education, Department of Elementary and Preschool Education
\end{abstract}

Received 6 October 2015; final version received 29 December 2015;

accepted 29 December 2015

\begin{abstract}
In 2008, a curricular reform was begun in Slovakia. It focused on introducing a two-level model of curriculum at pre-primary, primary and secondary schools. The reform has been met with mixed reactions from teachers and school administration staff. Our paper provides brief information on the nature of this reform,the content of the reform curricular documents and some of the results of a questionnaire survey regarding the attitudes of teachers in basic schools (primary and lower secondary level of education) towards the reform. Their ratings are examined in three areas: satisfaction with the development of the Slovak school system in the last six years, the importance of curricular changes and the effect of these changes.
\end{abstract}

Keywords: educational policy, curricular reform, teacher attitudes, basic school

The early 21st century could be described, from a certain point of view, as an era where global trends are a key factor of development. In the sphere of education such a global trend is a phenomenon called curricular or school reform. In spite of the fact that the reform processes can have a regional or local character, Cuban (2008) identified three phenomena that occur regardless of these possible geographical, cultural and historical particularities: a marketinspired definition of the educational problem; a common theory of change driving the solution to the market-inspired problem; and school and classroom outcomes (both anticipated and unanticipated) of these ambitious

1 This work was supported by the Slovak Research and Development Agency under the contract No. APVV-0713-12. 
efforts. These are the global motivation factors for a curricular reform with global features related to the preferred key values, functions and structures (Sahlberg, 2009). Slovakia is no different from other countries, as in 2008 the country underwent a principal curricular reform that should bring the Slovak schooling system in line with the global system of education.

In this paper, we present the results of a questionnaire survey on the attitudes of basic school teachers in Slovakia towards the curricular reform initiated in 2008 and their experience with the implementation of this reform. At first, we will outline the social and political context of the curricular reform in Slovakia, present the two-level curriculum system as a result of this reform and describe the course of the reform, which represented a contextual framework to shape the attitudes and experience of teachers. After that, we will describe the methodology and the outcomes of the questionnaire survey and we will interpret relevant findings.

\section{Curriculum reform in Slovakia}

For several centuries, Slovakia was an integral part of Hungary within the Austro-Hungarian Empire under the Habsburg dynasty. It was a state with a strong tendency for centralization of public administration, including the educational system. It had two typical features: a centralized, generally binding curriculum used as a tool of the state educational policy and the teacher implementing the state educational policy through the application of this curriculum. Those features also set the long-term historical path of education in the former Czechoslovakia and then in the Slovak Republic after its establishment in 1993.

In 1989, the change in the political situation allowed for major changes in education, schooling and the curriculum. The major turning point in the national curricular policy (systemic reform) that came in 1989 as a consequence of political changes was only truly felt in 2008. This was the introduction of a system with a two-level curriculum at pre-primary, primary and secondary schools. It was set as a generally binding standard by the 2008 Education Act.

The system of the two-level curriculum is represented by two key curriculum documents - the national curriculum titled The State Educational Programme representing the nationally binding curriculum and the school curriculum titled The School Educational Programme serving the autonomy of a particular 
school. By this political act, the Slovak educational system should become a part of what Sahlberg (2009) refers to as the Global Education Reform Movement - GERM. GERM represents a global phenomenon of transforming the efforts of developing educational systems through structural reforms towards higher quality and relevance (Hargreaves \& Goodson, 2006). Thus, the global priorities of educational reforms include categories such as curriculum development, school evaluation, evaluation of teachers, integration of ICT technologies into the education process, acquiring key competences, as well as literacy in natural sciences and mathematics (Sahlberg, 2009).

The State Educational Programme was developed as a set of curricular programmes on a national level for each type of school following the same general goals oriented towards the development of key competencies. A guarantee of educational quality at a generally accepted level is provided by the Educational Standards. These represent the requirements of the state for the educational outcomes at each level of education. The Framework Study Plan defines the minimum obligatory amount and structure of instruction in different types of school as well as the number and extent of obligatory subjects per week for each school grade.

The School Educational Programme contains detailed educational programmes based on the national curriculum developed by every school according to local conditions and specific orientation of each particular school.

Formally, this system of the two-level curriculum created the conditions necessary to to move the entire process of transformation within education towards real improvements of its quality:

However, it turned out that policy makers were not able to overcome the limits of the historically centralized mindset related to the changes they initiated. According to these traditions, the introduction of the two-level curriculum model was not seen as a process with actual processual phases (Janík et al., 2010a). Instead, it was seen as a one-off political act that used the teachers to implement it at schools ${ }^{2}$. Creating a school educational programme required a high level of decision-making autonomy for teachers, but they proved to be ill prepared for this task. Schools and their teachers got into a situation

2 The Education Act was adopted in May 2008 and schools were obliged to implement the twolevel curriculum model preparing their school educational programs for September of that same year, without any prior preparation. 
that Hargreaves (2008) describes as a consequence of insufficient time to reflect and plan, understand the curriculum, learn how to implement it, and catch up with professional literature. It proved that teachers feel the need to change, but become resistant to changes that are introduced in this fashion. As it has already been pointed out by many authors (Kirk \& McDonald, 2001; Hargreaves, 2008; Fullan, 1991), teachers are the key to curricular reform.

\section{The attitude of teachers towards curriculum reform}

The idea of a teacher-proof curriculum has long become obsolete (Stenhouse, 1975; Brundrett, Duncan, \& Rhodes, 2010; Priestley, 2011; Mutch, 2012). Many researches prove that teachers are the key protagonists of the whole process (Mutch, 2012). The attitude of teachers towards changes directly affects the level of their implementation into practice. It has been proven that subject expertise (Pimley, 2011), support of teacher development in terms of values, beliefs and competencies (Anderson, 1995) improve the motivation of teachers to participate in the decision-making process of the curriculum. According to the analytical framework created by Ho (2010) for participative decision making in the curriculum and pedagogy, both a high level of desired participation and a high level of actual participation of the teachers are the preferred conditions for success.

As pointed out by Kennedy \& Kennedy (1996) a curriculum reform based on the introduction of a two-level model, especially in the case of a decentralized process like in Slovakia, brings a host of potential problems. This is because teachers are not only being asked to change their roles and take on more responsibility, but they are also being asked to change previously held attitudes and beliefs. Decentralisation, in opposition to centralisation, is commonly characterised as leading to participation, relevance, ownership and (hence) increased commitment and motivation from those implementing the change, in our case, teachers (Kennedy, 1996). According to several authors (Brown, 1980; Haney, Czerniak, \& Lupe, 1996; Levitt, 2001), unless teachers' attitudes are compatible with the aims of the reform, they become resistant to the changes required. Teachers are not passive recipients of change even though the centuries of centralist traditions in Slovakia could suggest it. Many studies (Anderson et al., 1994; Connelly \& Clandinin 1988; Van Driel, Beijaard, \& Verloop, 2001) show that the experience, beliefs and attitudes of teachers crucially determine the ways to implement the required 
changes within curricular reform. If this experience, beliefs and attitudes in the process of curriculum reform are ignored, the implementation phase will most likely prove unsuccessful (Brown \& McIntyre, 1993). It is proven that when teachers are involved in the process of innovation from the initial idea to its implementation and review and if they receive the trust and respect from the leadership team, the chances for successful implementation of changes are much higher (Brundrett \& Duncan, 2011). If teachers were offered an opportunity to develop materials, plan together and share ideas with one another, then they would reform their teaching (Anderson, 1995). School values and teacher autonomy are significant predictors for motivation to change teaching methods $(\mathrm{Wu}, 2015)$.

\section{Research problem, objectives and questions}

Slovakia, in contrast to the Czech Republic (e.g. Janík et al., 2010b) has so far not carried out research that maps the experience, beliefs and attitudes of teachers regarding the implementation of the curriculum reform in 2008, even though seven years have elapsed since its introduction. For this reason, there is virtually nothing known about what the views of teachers are on the value of the reform, design of the curriculum content, implementation process, interaction with management and executive actors, or even the most important contextual aspects of the reform. This is what motivated the creation of a research project whose main objective is to find out as much as possible about what teachers of basic schools (primary and lower secondary level of education) in Slovakia think about the aforementioned topic.

This research project had three main objectives and they were formulated as follows:

(1) The first objective was to find out the level of teacher satisfaction with the development trend of the reformed education system for the last six years. This objective focused on the important time and value dimensions of the reform. It was further translated into the following research questions:

(1.1) In the respondents' view, is education getting importance in society?

(1.2) Do the respondents see positive changes in the school system?

(1.3) Do they consider the reform efforts comparable internationally?

(1.4) Are the respondents inclined to continue with the reform? 
(2) The second objective was to determine how urgent the respondents see the need for change in selected areas of the curriculum that was in force before the reform. This objective focused mainly on the motivation and values of curriculum innovation with reflection of the past. In order to achieve this objective, it was necessary to deal with the following questions:

(2.1) Did the respondents feel the need to change the objectives, content, methods and outcomes of education?

(2.2) Did the respondents feel the need for decentralization of power?

(2.3) Did the respondents feel the need to make the curriculum centered more on the student and the class as a group?

(3) The third objective focused on what the respondents consider as benefits of the curricular reform for their school. This objective was achieved through answers to the following questions:

(3.1) How do the respondents see the benefit of the reform specified for their school?

(3.2) How do they see the benefit of the reform for the working conditions of the teachers at their school?

(3.3) How do they see this benefit for the public acceptance of their school?

(3.4) How do they see the benefit of the reform for the effectiveness of education in their school?

(3.5) How do they see the benefit of the reform for their students?

\section{Method}

\subsection{Research plan and variables used}

The presented study is a part of a more complex project which takes the form of exploratory research ex post facto, based both on a relatively extensive questionnaire administered to a representative sample and on qualitative research and analysis of documents. In this paper, we present only part of the results of the questionnaire survey. 
We operationalised the research questions into the form of measurable variables, whereby several of them were created for each research question (not always the same number). The variables were grouped into three sets analogous to the three research objectives. The first group "Satisfaction with the state of education" had 6 variables, the second group "Need to change the curriculum" had 6 variables and the third group "Benefits of the reform" had 21 variables.

In order to obtain a more comprehensive evaluation describing the essence of each of the objectives, we calculated the averages across the groups of variables that we called indices. So there were three evaluation indices: Index of satisfaction with the development of education (abbreviated Satisfaction index), Index of urgency of curricular changes (abbreviated Urgency index) and Index of the benefits of the reform (abbreviated Benefit index). The Index is an aggregation of several subjective respondents, not objective reality of the school system.

\subsection{Procedure}

As a tool for the detection of all these variables, we constructed our own exploratory questionnaire IKR-2014, which functions under the principle of rating of each item. In this paper we build on the initial analysis of the first three groups of items (33 in total). All the items of one group have the same common initial instruction/statement or question (e.g. "I feel we need to change the curriculum in these areas"), which is subsequently specified in the form of a simple inventory with the associated rating scale (e.g. "1 Curriculum and teaching content, 2 Objectives and learning outcomes, etc.). It uses a four-point Likert scale without the middle range (e.g. definitely agree, somewhat agree, somewhat disagree, strongly disagree). The completed questionnaires were transcoded to a format of electronic datasets for MS Excel (and subsequently for SPSS) for processing. The quantitative processing was performed in stages, gradually going more in depth; at the time of writing of this paper, the initial stages had been completed.

\subsection{Population, sample, administration}

The target population consists of basic school teachers who have experience with the 2008 implemented curriculum reform. As such, we define the core set as all teachers in the state basic schools in Slovakia who were participating in the implementation of the curriculum reform in 2008. 
The research sample was selected through proportional stratified sampling. As the main criterion of stratification we chose the region (Slovakia has 8 regions) where the respondent worked during the period of the study. The respondents were sampled in compact groups. For each stratification group a list of all basic schools in the region was compiled. These lists were arranged according to a list of random numbers. For the sample $10 \%$ of schools from each stratification group were chosen. In total, we selected 63 schools.

We sent the questionnaire to all selected schools in April 2014. The time for the response was three months. The response rate was $76 \%$, which represents 954 respondents. Some more details about the sample are presented in Table 1 (the table only contains those characteristics of the respondents that are related to this paper).

Table 1

Research sample characteristics

\begin{tabular}{|c|c|c|c|c|c|}
\hline \multicolumn{2}{|c|}{ Research sample charateristics } & \multirow{2}{*}{$\begin{array}{c}\begin{array}{c}\text { Primary } \\
\text { level }\end{array} \\
\mathrm{N}\end{array}$} & \multirow{2}{*}{$\begin{array}{c}\begin{array}{c}\text { Lower } \\
\text { secondary } \\
\text { level }\end{array} \\
\mathrm{N}\end{array}$} & \multirow{2}{*}{$\begin{array}{c}\text { Both } \\
\text { levels } \\
\mathrm{N}\end{array}$} & \multirow{2}{*}{$\begin{array}{c}\text { No level indicated } \\
\mathrm{N}\end{array}$} \\
\hline & & & & & \\
\hline \multirow{2}{*}{$\begin{array}{l}\text { Current } \\
\text { position }\end{array}$} & Administration staff* & 33 & 47 & 4 & 5 \\
\hline & Teacher & 304 & 434 & 54 & 28 \\
\hline \multirow{8}{*}{$\begin{array}{l}\text { Years of } \\
\text { experience }\end{array}$} & Up to 5 years & 65 & 114 & 28 & 13 \\
\hline & $6-10$ years & 52 & 112 & 4 & 4 \\
\hline & $11-15$ years & 76 & 92 & 15 & 10 \\
\hline & $16-20$ years & 68 & 61 & 6 & 4 \\
\hline & $21-25$ years & 43 & 39 & 2 & 3 \\
\hline & $26-30$ years & 33 & 38 & 1 & 4 \\
\hline & 30 years and more & 14 & 33 & 2 & 2 \\
\hline & Not stated & 8 & 3 & 1 & 4 \\
\hline
\end{tabular}

* Administration staff are school principals and their deputies (they are teachers with a reduced teaching load, exercising management of the school within a defined period. For the purposes of this paper, we will not evaluate them separately).

\section{Results}

None of the distributions of the indices or sub-variables in the next three subsections met the criteria of normality (Shapiro-Wilk in Lilliefors modification) and therefore, it has no further significance. That is why 
the descriptive statistics indicates the parametric (average AM, standard deviation SD and confidence interval Clam) as well as the non-parametric measures (median MED, interquartile range IQRng a confidence interval for the median CImed). Likewise, we used mainly non-parametric procedures of inferential statistics.

\subsection{Satisfaction with the recent overall development of education}

Table 2 presents an overview of the descriptive and statistical data for a group of variables designed to assess the overall state of education in recent years. We used a four-point rating scale, where the values mean: 1 = strong dissatisfaction, 2 = moderate dissatisfaction, 3 = moderate satisfaction, 4 = strong satisfaction. In the first row of the table, the "Satisfaction index" is given as a calculation of the average of the partial variables scores (taking into account item polarity).

Table 2

Variables evaluating "satisfaction with the development of education"

\begin{tabular}{lcccccc}
\hline & AM & SD & Clam & Med & IQRng & CImed \\
\hline $\begin{array}{l}\text { Index of satisfaction with the development } \\
\text { of education }\end{array}$ & 2.05 & 0.53 & $2.01-2.08$ & 2.00 & 1.00 & $2.00-2.00$ \\
\hline $\begin{array}{l}106 r \text { - the reform of the educational } \\
\text { system should be abandoned and we } \\
\text { should go back to the state prior to 1989 }\end{array}$ & 2.65 & 0.98 & $2.57-2.72$ & 3.00 & 1.00 & $3.00-3.00$ \\
\hline $\begin{array}{l}105 \text { - so far, the situation is not very } \\
\text { satisfying, but the reform endeavors } \\
\text { should continue }\end{array}$ & 2.55 & 0.85 & $2.49-2.62$ & 3.00 & 1.00 & $3.00-3.00$ \\
\hline $\begin{array}{l}104 \text { - until now, the state of our } \\
\text { educational system is not satisfactory, } \\
\text { but all is on the path to improvement }\end{array}$ & 1.83 & 0.69 & $1.78-1.88$ & 2.00 & 1.00 & $2.00-2.00$ \\
\hline $\begin{array}{l}103 \text { - our reform in the educational } \\
\text { system is comparable to neighboring } \\
\text { countries }\end{array}$ & 1.83 & 0.70 & $1.78-1.88$ & 2.00 & 1.00 & $2.00-2.00$ \\
\hline $\begin{array}{l}101 \text { - the quality of citizen education has } \\
\text { become a priority in our society }\end{array}$ & 1.82 & 0.80 & $1.76-1.88$ & 2.00 & 1.00 & $2.00-2.00$ \\
\hline $\begin{array}{l}102 \text { - there is a significant positive } \\
\text { change in our educational system }\end{array}$ & 1.71 & 0.69 & $1.66-1.77$ & 2.00 & 1.00 & $2.00-2.00$ \\
\hline
\end{tabular}

Note. $\mathrm{AM}=$ arithmetic mean, $\mathrm{SD}=$ standard deviation, $\mathrm{CI}=95 \%$ confidence interval for $\mathrm{AM}$, Med $=$ median, $\mathrm{IQR}=$ interquartile range, $\mathrm{CIm}=$ confidence interval for median

The content inside of the analysed variables shows a relatively satisfactory Cronbach's alpha of 0.736. Although the individual variables were not 
considered part of one construct, but two related constructs at the beginning of the scale development, they have all been included in the calculation of the summarizing "Satisfaction index". Originally, we considered them to be two triads, i.e. the three variables $(101,102,104$ as a factor of the "system") related rather to a wider educational context of the reform and the three variables (103, 105 and 106 as a "reform" factor) directly concerning the reform itself. Exploratory factor analysis also roughly revealed this structure (the factors explaining $41 \%$ and $24 \%$ of the variance), except for variable 103 , which is empirically related rather to the wider context (although the wording of this item contains the term "reform"). The non-parametric version of variance analysis for repeated measures (Friedman) also confirms a statistically significant more positive score for 106 and 105 in comparison to all the other variables in the group.

\subsection{The perception of the urgency of changes in the curriculum}

The descriptive characteristics of the variables focusing on the urgency of curricular changes in recentyears are presented in Table 3. These are theresults of the rating scales with this meaning: 1 = not at all urgent, 2 = rather unurgent 3 = rather urgent, $4=$ highly urgent. The overall Index of urgency of curricular changes is calculated as the average of all numbered variables in this table.

Table 3

Variables evaluating "the urgency of curricular changes"

\begin{tabular}{|c|c|c|c|c|c|c|}
\hline & $\mathrm{AM}$ & SD & CIam & Med & IQR & CImed \\
\hline Index of urgency of curricular changes & 2.83 & 0.61 & $2.79-2.87$ & 2.83 & 1.00 & $2.83-2.91$ \\
\hline $\begin{array}{l}206 \text { - supporting a positive climate in } \\
\text { classroom }\end{array}$ & 3.25 & 0.77 & $3.20-3.31$ & 3.00 & 1.00 & $3.00-3.00$ \\
\hline $\begin{array}{l}204 \text { - updating the methods, strategies } \\
\text { and forms of teaching }\end{array}$ & 3.20 & 0.75 & $3.15-3.25$ & 3.00 & 1.00 & $3.00-3.00$ \\
\hline $\begin{array}{l}205 \text { - higher level of acceptance for } \\
\text { learners'personal individualities }\end{array}$ & 2.96 & 0.74 & $2.91-3.01$ & 3.00 & 0.00 & $3.00-3.00$ \\
\hline $\begin{array}{l}202 \text { - objectives and educational } \\
\text { outcomes }\end{array}$ & 2.56 & 0.82 & $2.51-2.62$ & 3.00 & 1.00 & $3.00-3.00$ \\
\hline 201 - teaching material and content & 2.52 & 0.89 & $2.46-2.58$ & 3.00 & 1.00 & $2.00-3.00$ \\
\hline $\begin{array}{l}203 \text { - decentralization of power and } \\
\text { the need to create school educational } \\
\text { programmes }\end{array}$ & 2.47 & 0.88 & $2.40-2.53$ & 2.00 & 1.00 & $2.00-3.00$ \\
\hline
\end{tabular}

Note. $\mathrm{AM}=$ arithmetic mean, $\mathrm{SD}=$ standard deviation, $\mathrm{CI}=95 \%$ confidence interval for $\mathrm{AM}$, Med = median, $\mathrm{IQR}=$ interquartile range, $\mathrm{CImed}=$ confidence interval for median 
The relatively high Cronbach's alpha within this group of items (0.836) suggests a good consistency of the content within the analyzed grouping. Exploratory factor analysis indicated a two-factor solution (two factors with 37\% saturation): the first three variables (201-203 "educational efficiency" factor), and the second three variables (204-206 "innovation humanity" factor). In the descending order of urgency of changes according to AM, the highest ranked variable was 204 (the need to promote positive climate) and 206 (the need for innovations in the methods, strategies and forms of teaching). The Friedman test followed by post hoc tests identified statistically relevant differences in the scores of variables 201, 202, 203 of "educational efficiency" factor compared to the other variables (this is consistent with the findings of the factor analysis).

\subsection{Benefits of the curricular reform}

Table 4 shows the descriptive characteristics of the variables focusing on areas in which respondents indicated a need for curricular changes. The values of the four-level rating scale have this meaning: 1 = no benefit, 2 = largely without benefit, 3 = moderately beneficial, $4=$ greatly beneficial. The total Index of the benefits of the reform is calculated as the arithmetic mean of all sub-items scores. We deliberately took the information in this field out of numerical order (to make it clearer, we dropped some of the variables in ranking that had low differences).

Table 4

Variables evaluating "the benefits of the reform"

\begin{tabular}{lcccccc}
\hline & AM & SD & CIam & Med & IQR & CImed \\
\hline Index of the benefits of the reform & $\mathbf{2 . 5 0}$ & $\mathbf{0 . 5 8}$ & $\mathbf{2 . 4 7 - 2 . 5 4}$ & $\mathbf{2 . 5 0}$ & $\mathbf{1 . 0 0}$ & $\mathbf{2 . 4 6 - 2 . 5 7}$ \\
\hline $\begin{array}{c}301 \text { - greater opportunity to profile the } \\
\text { school }\end{array}$ & 2.82 & 0.74 & $2.77-2.87$ & 3.00 & 1.00 & $3.00-3.00$ \\
\hline $\begin{array}{c}302-\text { closer links between school and } \\
\text { practice }\end{array}$ & 2.45 & 0.80 & $2.40-2.50$ & 2.00 & 1.00 & $2.00-3.00$ \\
\hline $\begin{array}{c}303 \text { - possibility to take into account } \\
\text { regional specificities for the school }\end{array}$ & $\mathbf{2 . 8 9}$ & 0.68 & $2.85-2.94$ & 3.00 & 0.00 & $3.00-3.00$ \\
\hline $\begin{array}{c}304-\text { improvement of the } \\
\text { communication of the school with } \\
\text { families of students }\end{array}$ & 2.37 & 0.84 & $2.32-2.42$ & 2.00 & 1.00 & $2.00-2.00$ \\
\hline 305 - greater freedom for teachers & 2.52 & 0.83 & $2.47-2.58$ & 3.00 & 1.00 & $3.00-3.00$ \\
\hline
\end{tabular}




\begin{tabular}{|c|c|c|c|c|c|c|}
\hline & $\mathrm{AM}$ & SD & CIam & Med & $\mathrm{IQR}$ & CImed \\
\hline $\begin{array}{l}306 \text { - improvement of the work of the } \\
\text { teaching staff }\end{array}$ & 2.31 & 0.80 & $2.25-2.36$ & 2.00 & 1.00 & $2.00-2.00$ \\
\hline $\begin{array}{l}307 \text { - improvement ofthe management of } \\
\text { work in schools }\end{array}$ & 2.49 & 0.81 & $2.43-2.54$ & 3.00 & 1.00 & $2.00-3.00$ \\
\hline $\begin{array}{l}308 \text { - improvement of the climate and } \\
\text { atmosphere of schools }\end{array}$ & 2.30 & 0.82 & $2.24-2.35$ & 2.00 & 1.00 & $2.00-2.00$ \\
\hline $\begin{array}{l}309 \text { - positive pedagogical thinking of } \\
\text { teachers }\end{array}$ & 2.33 & 0.80 & $2.27-2.38$ & 2.00 & 1.00 & $2.00-2.00$ \\
\hline $\begin{array}{l}310 \text { - more positive views of parents } \\
\text { about the school }\end{array}$ & 2.38 & 0.77 & $2.32-2.43$ & 2.00 & 1.00 & $2.00-2.66$ \\
\hline $\begin{array}{l}311 \text { - improvement of the public view of } \\
\text { the school }\end{array}$ & 2.40 & 0.79 & $2.35-2.45$ & 2.00 & 1.00 & $2.00-3.00$ \\
\hline $\begin{array}{l}312 \text { - improvement of the quality of work } \\
\text { at school }\end{array}$ & 2.49 & 0.78 & $2.44-2.54$ & 3.00 & 1.00 & $2.00-3.00$ \\
\hline $\begin{array}{l}313 \text { - modernization of educational } \\
\text { concepts }\end{array}$ & 2.71 & 0.75 & $2.67-2.76$ & 3.00 & 1.00 & $3.00-3.00$ \\
\hline $\begin{array}{l}314 \text { - improvement of teaching } \\
\text { managementat school }\end{array}$ & 2.59 & 0.75 & $2.53-2.64$ & 3.00 & 1.00 & $3.00-3.00$ \\
\hline 315 - improvement of educational goals & 2.53 & 0.73 & $2.48-2.58$ & 3.00 & 1.00 & $2.00-3.00$ \\
\hline $\begin{array}{l}316 \text { - improvement of educational } \\
\text { content (curriculum) }\end{array}$ & 2.42 & 0.78 & $2.37-2.47$ & 2.00 & 1.00 & $2.00-3.00$ \\
\hline $\begin{array}{l}317 \text { - improvement of methods and } \\
\text { forms of teaching }\end{array}$ & 2.69 & 0.74 & $2.65-2.74$ & 3.00 & 1.00 & $3.00-3.00$ \\
\hline $\begin{array}{l}318 \text { - possibility to factor for individual } \\
\text { needs of students }\end{array}$ & 2.73 & 0.73 & $2.68-2.78$ & 3.00 & 1.00 & $3.00-3.00$ \\
\hline $\begin{array}{l}319 \text { - greater activity and creativity of } \\
\text { students }\end{array}$ & 2.65 & 0.77 & $2.60-2.70$ & 3.00 & 1.00 & $3.00-3.00$ \\
\hline 320 - greater student interest in learning & 2.10 & 0.83 & $2.04-2.15$ & 2.00 & 1.00 & $2.00-2.00$ \\
\hline $\begin{array}{l}321 \text { - improvement of learning results of } \\
\text { students }\end{array}$ & 2.18 & 0.82 & $2.12-2.23$ & 2.00 & 1.00 & $2.00-2.00$ \\
\hline
\end{tabular}

Note. $\mathrm{AM}=$ arithmetic mean, $\mathrm{SD}=$ standard deviation, $\mathrm{CI}=95 \%$ confidence interval for $\mathrm{AM}$, Med $=$ median, $\mathrm{IQR}=$ interquartile range, $\mathrm{CImed}=$ confidence interval for median

The extremely high Cronbach's alpha (0.966) in this case has more negative connotation: it indicates a high similarity of scores of individual variables, i.e. a reduced differentiation power of the entire group of items. Factor analysis helped to organize the 21 variables in this four-factor model: a powerful factor saturated by variables 304-312 ("teacher" factor) and three weaker 
factors saturated by variables 313-321 ("educational methods"), variables 301-303 ("benefits for school"), and variables 320 and 321 ("student" factor). Non-parametric analysis of the variance again shows statistically significant differences in certain pairs of variables. Substantive significance, (for here, only estimated in terms of the overlapping confidence intervals) would be relatively uninteresting.

\section{Discussion}

\subsection{Comments and interpretations}

The following part contains a brief summary of findings related to individual research objectives and questions.

The first objective was to find out the level of teacher satisfaction with the development trend of the reformed education system for the last six years. Our findings about the individual issues were as follows:

(1.1) Is education getting importance in society? 8 out of 10 respondents believe that education being seen as a priority has not happened. $36 \%$ strongly agreed with this statement, while another $45 \%$ were inclined to have this opinion.

(1.2) Do the respondents see positive changes in the school system? Up to 41\% of them see no positive changes in the school system and another $44 \%$ see only a slight positive change in the school system.

(1.3) Are the reform efforts internationally comparable? Disconcent was quite apparent.While $44 \%$ were in moderate opposition, $28 \%$ voiced strong disapproval. For this entry, 13\% voiced no opinion.

(1.4) Are the respondents inclined to continue with the reform? 11\% want to continue the reform while $12 \%$ would like for it to be discontinued. The milder opinion had $40 \%$ for reform and $30 \%$ against its continuation. $13 \%$ still agree with the extreme statement "the reform should be ended and we should return to the system that was in place before 1989" (i.e. in the socialist era).

The Index of satisfaction with the development of education has a value of 2.5 , corresponding to a typical evaluation position of "mild discontentment". Partial factors, however, reveal two more diverse views: a more optimistic ("the reform" around 2.6) and a more pessimistic ("the system" around 1.8). 
Together, these variables can represent up to three different indications: the majority of respondents wish to have the reform, they do not consider it internationally competitive and also the development of the national education system is considered undesirable.

The second objective to determine how urgent the respondents see the need for change in selected areas of the curriculum that was in force before the reform led to the following findings:

(2.1) Did the respondents feel the need to change the objectives, content, methods and outcomes of education? The strongest need for change is felt in the "modernization of methods, strategies and forms of learning". 8 out of 10 respondents found the need for change to be highly urgent. With "changes in the objectives and education outcomes", 43\% of the respondents felt the need, yet only $8 \%$ felt it was urgent. Only 5 from 10 felt a need for changes in the "curriculum and teaching content".

(2.2) Did the respondents feel the need for decentralization of power? Here there is a slight polarization of opinions: $42 \%$ wanted decentralization; $45 \%$ did not. Only about 1 in 10 considered it to be urgent.

(2.3) Did the respondents feel the need to make the curriculum centered more on the student and the class as a group? This was the strongest rating expressing a need. Up to 9 out of 10 respondents indicated the need for "a stronger influence of the curriculum to create a positive atmosphere in the classroom". 51\% of the respondents wished for "increased acceptance of the specific needs and peculiarities of the students".

The urgent need for curricular change was proven to be rather strong by the respondents, but not all components of the curriculum were viewed the same. The Index of urgency of curricular changes reached 2.83, corresponding to a rating of "moderate reformist position". Within the structure of this index, this position was contributed by an intrinsic factor, which we call "innovation humanity" (e.g. climate in the classroom, specifics of students) in contrast to the factor of "educational efficiency" (e.g. curriculum and teaching content).

The third objective was to identify what the respondents consider as benefits of the curricular reform for their school. Our answers to each question are as follows: 
(3.1) How do the respondents see the benefit of the reform specified for their school? Nearly $75 \%$ of respondents think that the benefits of the reform are the "taking better into account the regional differences of schools". 7 out of 10 think that the reform has brought "more opportunities to profile their school". Half of the respondents view the reform as resulting in an improved quality of work in their school.

(3.2) How do they see the benefits of the reform for the working conditions of teachers at their school? A slight majority think that the reform "has brought greater freedom for teachers". In contrast, however, 6 out of 10 respondents believe "the reform has resulted in no positive change in the thinking of teachers". In the "improvement of teachers", the opinions are polarized. Every second respondent thinks "there was a management improvement in their school work" (but only 7\% strongly believed this). 6 out of 10 take the position that the reform "did not bring work improvement of the teaching staff". 56\% believe that the reform "had no impact on improving the climate and atmosphere at their school".

(3.3) How do they see this benefit for the public acceptance of their school? Almost every second respondent thinks that the reform "did not bring change in the public view of their school". 6 out of 10 teachers think "the reform improved the communication with the families of students".

(3.4) How do they see the benefit of the reform for the effectiveness of education in their school? 7 out of 10 respondents agree with the statement "the reform has brought to their schools a more modern concept of education" and 51\% agree with the fact that "the reform has improved the process of teaching at their school". 6 out of 10 agreed with the statement that "the reform has brought quality improvement in methods and forms of teaching". "Improving the quality of educational objectives" was recognized by $51 \%$ of respondents. 5 out of 10 of those surveyed however, think "the reform did not bring improvement of teaching content".

(3.5) How do they see the benefit of the reform for their students? 60\% think "the reform did not bring improvement of educational results of students". Only $5 \%$ of respondents strongly agreed with the statement of a positive impact of the reform on student achievement. We found the following paradox: 6 out of 10 respondents agreed "the reform has brought greater activity and creativity of students" in their schools, however, 7 out of 10 felt 
"there is no change in the interest of students towards learning". From these respondents, half strongly believe so. The most powerful benefit of the reform the respondents identified with was "taking into account the individual needs of students in their school" (64\% hold this view, while the opposite view was only $5 \%$ ).

The Index of the benefits of the reform (2.50) reveals the predominance of slightly positive evaluations for most of these areas (with the highest contribution to the regional school profile, in contrast to the lowest contribution to the motivation of students). The evaluations of this aspect are mutually less discriminating, though it can be seen that the respondents used a slightly different evaluation model in areas related to the teaching profession ("teacher" "factor") compared to the other three ("educational methods", "benefits for school" and "student" factor).

\subsection{Limits and advantages of the study}

The main shortcomings of our research are as follows:

The pilot group was not very extensive. The questionnaire was validated primarily through focus groups. The objectivity would increase if there were a larger sample of teachers.

A strong retrospective effect. The research was asking about the reform after a long period of time (over 5 years). The responses may not be representative of the respondents' true feeling of the reform.

Problems with normality of the sampling distribution. This can be linked to an asymmetrical distribution of ratings (division of the phenomenon), as well as the lower number of stages in the evaluation scale. This reduces the room to maneuver the statistical analysis to estimate the impact on the basic set.

Local "projective" potential of the terminology used. Not all terms in each item could be construed as consistent by the respondents. This leaves open the possibility of "shaping" issues and it may affect the validity of the particular research tool. This deficiency, however, should be compensated by simultaneous qualitative research.

The weaker differentiation potential in the third group of items. Some items measure the same thing. The research findings would be more comphrensive if the number of entries was reduced and if the entries were structured into different thematic groups. 
The main advantages of our research are as follows:

The uniqueness of the intent. This research is the only attempt in the Slovak Republic to systematically map the opinions of teachers about the reform of 2008. It was created as a platform for further research into curriculum innovations in Slovakia.

Comparative dimension. The research does not ignore similar studies in the Czech Republic. The results can be compared with the results not only in this country but also in other countries.

Conceptual preparation. The questionnaire was designed to cover the different areas of the conceptual map of the problem. It was created on the basis of theoretical analysis of the curriculum reform by specialists in the primary and lower secondary level of education system in the Slovak Republic.

The quality and range of the sample. The research covered $10 \%$ of the core set of the population. It was conducted by stratification method, which was strictly applied to a random selection.

High return. The questionnaires did not have to be re-administered, thus all respondents' opinions came from the same time period.

The time gap. The disadvantage of the aforementioned time period has possible positive consequences. The respondents' answers are certainly missing the extremity of immediate reactions and are based on longer-term experience with the studied phenomenon.

\section{Conclusions}

This paper presents the attitudes of basic school teachers towards the curricular reform in Slovakia as a determining factor of its success. Similar to findings from other authors (Janík et al., 2010a, b), in Slovakia we can also observe a certain ambivalence about these attitudes. On the one hand, we see signs of dissatisfaction leading to a dismissive attitude to the ongoing reform; on the other hand, people feel a necessity for curricular changes. Our questionnaire examined three thematic areas that could indicate the way this widely discussed issue is reflected in the specific conditions of the Slovak curricular reform at basic schools. 
The first examined area concerned the overall satisfaction of teachers with the recent development of the education system in Slovakia. It was proven that there is a rather large group of teachers that believe the curricular model used before 1989 was better than the current one. As this curricular model was applied in a non-democratic political environment, this phenomenon requires deeper analysis that reaches beyond the capacity of this paper. However, it brings some optimism that most of the teachers, as well as administration workers, despite their critical opinions, declared the need for changes in the school system. This finding is supported by the mostly positive responses for items of the second examined area that concerns their feelings of urgency for a need to make changes in the pre-2008 curriculum. The level of respondents' disappointment with the current reform proves that the aims and goals of the curricular reform planned by the educational policy makers did not meet the expectations of teachers at basic schools. The curricular reform initiated in 2008 mainly brought decentralization of decision-making competences towards a higher curricular autonomy of schools, especially in the area of managing the teaching contents. Teachers, however, expected more changes in creating a positive climate in the classrooms, in teaching methods and forms, and in the possibilities for encouraging individual approach during instruction. This is probably one of the key factors that determine the attitudes of basic school teachers towards the reform. This assumption is also supported by the score from the respondents' answers in the third examined area related to the positive impacts of the curricular reform. Here, the respondents assigned the highest score to the reform's positive impact on students' learning habits and improvement of their educational performance.

Our findings confirm that, just like the case of curricular reforms in the rest of the world (Daly \& Finnigan, 2010; Lee \& Yin 2011; Mutch, 2012; Mouraz, Leite, \& Fernandes, 2013), the key determinant of the Slovak curricular reform success is the teacher. However, teachers' key role is not only based on their level of autonomy as the implementators and performers of the national curriculum in the local environment. It is becoming obvious that the level of acceptance of their opinions on the planned curricular changes by the authorities in power that form the educational and curricular policy is just as important. 


\section{References}

Anderson, R. D. (1995). Curriculum reform: Dilemmas and promise. Phi Delta Kappa International Stable, 77(1), 33-36.

Anderson, R. D., Anderson, B. L., Varnaka-Martin, M. A., Romagnano, L., Bielenberg, J., Flory, M., Mieras, B., \& Whitworth, J. (1994). Issues of curriculum reform in science, mathematics and higher order thinking across the disciplines. The Curriculum Reform Project, University of Colorado. U.S. Department of Education, Office of Educational Research and Improvement.

Brown, M. A. (1980). Attitudes and social categories: complementary explanations of innovationadoption behavior. Environment and Planning A, 12(2), 175-186.

Brown, S., \& McIntyre, D. (1993). Making sense of teaching. Buckingham: Open University Press.

Brundrett, M., Duncan, D., \& Rhodes, C. (2010). Leading curriculum innovation in primary schools project: An interim report on school leaders' roles in curriculum development in England. Education 3-13: International Journal of Primary, Elementary and Early Years Education, 38(4), 403-419.

Brundrett, M., \& Duncan, D. (2011). Leading curriculum innovation in primary school. Management in Education, 25(3), 119-124.

Connelly, F. M., \& Clandinin, D. J. (1988). Teachers as curriculum planners. New York: Teachers College Press.

Cuban, L. (2008). US school reform and classroom practice. In C. Sugrue (Ed.), The future of educational change (pp. 75-88). London: Routledge.

Daly, A. J., \& Finnigan, K. S. (2010). A bridge between worlds: Understanding network structure to understand change strategy. Journal of Educational Change, 11(2), 111-138.

Fullan, M. (1991). The new meaning of educational change. New York: Teacher College Press.

Haney, J. J., Czerniak, C. M. \& Lumpe, A. T. (1996). Teacher beliefs and intentions regarding the implementation of science eduction reform strands. Journal of Research in Science Teaching, 33(9), 971-993.

Hargreaves, A. (2008). The fourth way of change: Towards an age of inspiration and sustainability. In A. Hargreaves \& M. Fullan (Eds.), Change wars (pp. 11-40). Toronto: Solution Tree.

Hargreaves, A., \& Goodson, I. (2006). Educational change overtime? The sustainability and nonsustainability of three decades of secondary school change and continuity. Educational Administration Quarterly, 42(1), 3-41.

Ho, D. CH. W. (2010). Teacher participation in curriculum and pedagogical decisions: Insights into curriculum leadership. Educational Management Administration Leadership, 38(5), 613-624.

Janík, T., Janko, T., Knecht, P., Kubiatko, M., Najvar, P., Pavlas, T., Slavík, J., Solnička, D., \& Vlčková, K. (2010a). Kurikulární reforma na gymnáziích: výsledky dotazníkového šetření [The curriculum reform at grammar school: Questionnaire survey; in Czech]. Praha: Výzkumný ústav pedagogický v Praze.

Janík, T., Knecht, P., Najvar, P., Pavlas, T., Slavík, J., \& Solnička, D. (2010b). Kurikulární reforma na gymnáziích $v$ rozhovorech s koordinátory pilotních a partnerských škol [The curriculum reform at gymnasium: Interviews with coordinators at pilot and partner schools; in Czech]. Praha: Výzkumný ústav pedagogický v Praze.

Kennedy, C. (1996). Teacher roles in curriculum reform. ELTED, 2(1), 77-89. 
Kennedy, C., \& Kennedy, J. (1996). Teacher attitudes and change implementation. System, 24(3), 351-360.

Kirk, D., \& MacDonald, D. (2001). Teacher voice and ownership of curriculum change. Journal of Curriculum Studies, 33(5), 551-567.

Lee, J. C.-K., \& Yin, H-B. (2011). Teachers' emotions and professional identity in curriculum reform: A Chinese perspective. Journal of Educational Change, 12(1), 25-46.

Levitt, K. (2001). An analysis of elementary teachers' beliefs regarding the teaching and learning of science. Science Education, 86(1), 1-22.

Mouraz, A., Leite, C., \& Fernandes, P. (2013). Teachers' role in curriculum design in Portuguese schools. Teachers and Teaching: theory and practice, 19(5), 478-491.

Mutch, C. (2012). Curriculum change and teacher resistance. Curriculum Matters, 8(1), 1-8.

Pimley, G. (2011). Curriculum autonomy through curriculum expertise. Forum for promoting comprehensive education, 53(1), 93-99.

Priestley, M. (2011). Schools, teachers, and curriculum change: A balancing act? Journal of Educational Change, 12(1), 1-23.

Sahlberg, P. (2009). Learning first. School accountablity for sustainable society. In D. G. Kenneth, L. S. Brenda, \& J-C. Couture (Eds.), Education accountability. Proffesional voices from the field (pp. 1-22). Rotterdam: Sense Publishers.

Stenhouse, L. (1975). An introduction to curriculum research and development. London: Heinemann.

Van Driel, J. H., Beijaard, D., \& Verloop, N. (2001). Professional development and reform in science education: The role of teachers' practical knowledge. Journal of Research in Science Teaching, 38(2), 137-158.

$\mathrm{Wu}$, S. M. (2015). Development and application of the measures of school value, teacher. The New Educational Review, 39(1), 240-250.

Zákon č. 245/2008 Z.z. z 22. mája 2008 o výchove a vzdelávaní (školský zákon). [Education Act No. 245/2008]. Available https://www.minedu.sk/data/att/9287.pdf.

\section{Authors}

Štefan Porubský, Matej Bel University in Banská Bystrica, Faculty of Education, Educational Research Center, Ružová 13, 97411 Banská Bystrica, Slovak Republic, e-mail: stefan.porubsky@umb.sk

Marian Trnka, Matej Bel University in Banská Bystrica, Faculty of Education, Department of Elementary and Preschool Education, Ružová 13, 97411 Banská Bystrica, Slovak Republic, e-mail: marian.trnka@umb.sk

Vladimír Poliach, Matej Bel University in Banská Bystrica, Faculty of Education, Department of Psychology, Ružová 13, 97411 Banská Bystrica, Slovak Republic, e-mail: vladimir.poliach@umb.sk

Radka Cachovanová, Matej Bel University in Banská Bystrica, Faculty of Education, Department of Elementary and Preschool Education, Ružová 13, 97411 Banská Bystrica, Slovak Republic, e-mail: radka.cachovanova@umb.sk 


\title{
Kurikulární reforma na Slovensku v pohledech učitelů základních škol
}

\begin{abstract}
Abstrakt: V roce 2008 začala na Slovensku kurikulární reforma. Ta zavedla dvouúrovňový systém kurikula $\mathrm{v}$ rámci předškolního, základního i středního vzdělávání. Setkala se se smíšenými reakcemi, jak od učitelů, tak od vedení škol. Tento př́spěvek stručně představuje tuto reformu, obsah základních kurikulárních dokumentů a některé $\mathrm{z}$ výsledků dotazníkového šetření zaměřeného na postoje učitelů základních škol k reformě. Jejich názory byly sledovány ve třech oblastech: spokojenost s vývojem školského systému na Slovensku v posledních šesti letech, důležitost kurikulárních změn a jejich dopad.
\end{abstract}

Klíčová slova: vzdělávací politika, kurikulární reforma, postoje učitelů, základní škola 